\title{
A Review of Industrial Paraffin Production Technologies Based on Recent Developments
}

\section{Hassanpour $\mathbf{M}^{*}$ \\ Department of Environmental Science, UCS, Osmania University, India}

*Corresponding author: Malek Hassanpour, Department of Environmental Science, UCS, Osmania University, Telangana, India, Tel: 091-8978811723; Email: Malek.hassanpour@ yahoo.com

\section{Review Article \\ Volume 5 Issue 2}

Received Date: May 16, 2021

Published Date: June 02, 2021

DOI: $10.23880 /$ ppej-16000264

\section{Abstract}

Lubrication or tribology, which is the science of facilitating the relative motion of surfaces in contact with each other, is one of the most important disciplines in science, technical knowledge, and engineering operations today. Regarding the vast application of Industrial Paraffin (IP) in daily life and the existence of numerous oil wells, the current review discussed IP production technologies and applications of IP in many human demands in the framework of a project and its public involvements. It was summarized the recent technologies posed in IP production from valid and available databases to demystify the existing alternatives. The information of assessed projects in the Environmental Impact Assessment (EIA) plan was offered to access the framework of the initial assessment of the evaluator team in the screening step of project identification. The review of developed technologies surged the interests of decision-maker for pushing the industrial projects towards decision theory to make the matrix of data for further assessment depend on the quality and quantity of the requested product. The conclusion of the current review ended up attracting decision-maker opinion to mitigate the hazardous and health effects of introduced technologies by selecting the best alternative in IP production operation.

Keywords: Industrial paraffin; Technologies; EIA; Projects; Oil

\section{Introduction}

Lubrication or tribology, which is the science of facilitating the relative motion of surfaces in contact with each other, is one of the most important disciplines in science, technical knowledge, and engineering operations today. Whenever the surfaces of objects in relative proximity and contact with each other are relatively moving, there will be two phenomena of friction and wear. Friction is the force of resistance to relative motion and the passage of surfaces in contact with each other. Wear is the act of destruction and rupture of material particles that results from the contact of surfaces in relative motion and terms of the force of friction
[1]. Let's see what can be considered as a qualified lubricant. Further efforts to find effective lubricants have a long history. Many materials have been tested for this purpose over time and then discarded and replaced with better materials. But some of the lubricants used to date are surprisingly old-fashioned alternatives. In $1400 \mathrm{BC}$, the Romans and Egyptians boiled a mixture of melted fat and melted tallow with lime soap and used it to lubricate vehicle axles and as grease to the wheels of chariots. It was not until about the middle of the last century that lime oil and soap became the main lubricants for industrial purposes. Lubricants used in today's industrial world can be compared to gas; liquid; Semi-solid, and solidified lubricants. In the production of raw 


\section{Petroleum \& Petrochemical Engineering Journal}

materials for manufacturing IP, crude oil is used, which is of special importance in determining the hydrocarbons present in the processing of crude oil. Basically, the compounds in petroleum products are components of hydrogen and carbon. There are other compounds such as a small quantity of sulfur, oxygen, and nitrogen. Oxygen is mostly present in the form of naphthenic acids and nitrogen in the form of naphthenic base oils. Sulfur can also be present in the form of free sulfur, soluble or hydrogen sulfide, or organic compounds. Metal compounds are reported in the PPM range. The major hydrocarbons derived from crude oil are classified into three main groups, and the characteristics of each base oil vary depending on what percentage of it is present in the oil. The paraffinic group is a linear chain or branched saturated hydrocarbon compounds which are obtained in large quantities from crude oils from paraffinic crude oil. Naphthenic hydrocarbons are saturated hydrocarbons that are similar to paraffin and are composed of the bonding of methylene groups arranged in a ring. Aromatic hydrocarbons contain a very wide range of cyclic compounds that are semisaturated. The cyclic compounds can be chain hydrocarbons, thus creating a myriad of different compounds. This type of structure reacts more easily than paraffin and naphthenic compounds and turns into corrosive resin and asphalt by-products. Another feature is that it is easier to form emulsions with water due to less surface tension. In the process of producing the IP from crude oil, distillation, refining, chemical refining, asphalting, and de-waxing units are implemented [2-4].

Despite too many useful applications of paraffin compounds, many studies moved towards removal options in petroleum exploitation from oil wells. The dissociation of paraffin deposits has been reported by Youssef, et al. [5] via hydrocarbon metabolizing microorganisms. In research of Jinfeng, et al. [6] used microorganisms to breakdown the paraffin residues in an oil well. The supplementary nutrients and required substrates have been added to the effective growth of strains. Using Arthrobacter sp, Pseudomonas sp, and Bacillus sp resulted in a decline of paraffin concentration from 29.8 to $25.5 \%$ in 9 months. A significant dissociation efficiency has been confirmed by the study of Lazar, et al. [7] on both forms of solid and semi-solid paraffin components. The same significance in paraffin removal efficiency reported by Hao, et al. [8] and Nelson and Schneider [9]. Bailey, et al. [10] asserted conversion of paraffin to unsaturated olefins. The partial degradation of paraffin to intermediate components has been reported by Lazar, et al. [7]. It facilitated the dissociation of this compound to the final products of bio-solvents and bio-surfactants. The reasons for conducting these kinds of studies get back to challenges that emerged in crude oil exploitation in many nations such as Kuwait, Qatar, Uganda, and South Sudan with a high quantity of paraffin wax concentration. The high-energy magnets of rare-earth materials impede the formation of the deposits of asphalt, resin, and paraffin in oil wells via installing magnets supported by electric charges into pipelines. The use of Ecowave TM, chemical inhibitors, dispersants, detergents, and ultrasonic waves are other recommended practices in this regard. The main methods of paraffin removal from oil wells can be mentioned as (1) mechanical (cutting, scrapping, erosion, and explosion, etc), (2) thermal (simple heating methods to complex processes like using plasma flames), (3) chemical (a variety of solvents, detergents, and similar compounds), and (4) microbial [11-14].

The crude oil possessed various proportions of paraffin wax ranged around $3-44 \%$. The viscosity of crude oil deeply depends on the concentration of paraffin wax. So, the high existing viscosity in crude oil solidifies and crystallizes the crude oil exploitation operation as well as other difficulties such as pressure drop, gelation structure, lower mobility that can cause higher outlays for pump stations $[15,16]$. The composition of waxes made up mostly from aliphatic and nonpolar components holding a heavy molecular chain with restricted mobility in crude oil with relatively high ability in the crystallization process. Both solid and semi-solid forms of waxes vary depend on pressure and temperature to liquid and even gas states [17]. The density and heat capacity of paraffin waxes has been reported to be around $900 \mathrm{~kg} / \mathrm{m}^{3}$ and $2.14-2.9 \mathrm{~J} \cdot \mathrm{g}^{-1} \cdot \mathrm{K}^{-1}$ respectively. The prominent ingredients of paraffin (Alkanes) are methane, ethane, propane, butane, pentane, and hexane [18].

Paraffin is used to preserve and storage human body tissues all over the world. This achievement is one of the important applications of paraffin in medical usages [19]. The interests surged towards the use of paraffin-based biofuel in the aviation sector due to proper cooling conditions, appropriate formulation for hydrocarbons structure, an escalated energy yield, low level of impurities, and high blending ability with other fuels [20].

The demand for industrial waxes followed a dramatic growth of $1.5-2 \%$ annually and mainly for packaging usages. Universally, the demand (for bio-based, synthetic, and fossil-based waxes) ranged around 4.79 million tons with a purchasing cost of 6.7 billion USD in the market. The produced waxes from petroleum are introduced as petrolatum, paraffin, and microcrystalline waxes. The montan and ozokerite are mineral waxes of fossil-based minerals derived from coal that its origin refers to petroleum too. The Fischer-Tropsch process produces synthetic waxes via chemical interaction between gaseous products. Some other types of waxes were derived from animals, vegetables, plants, castor, soy, etc. But the majority of waxes (85-90\%) available in the global markets are originated from petroleum waxes. The synthetic waxes placed the second rank in the demand of markets 
[21]. Paraffin waxes are released during refining lubricant oils which are composed of saturated heavy hydrocarbons possessing $\mathrm{C}_{18}$ to $\mathrm{C}_{60}$, and predominantly greater than $\mathrm{C}_{25}$. The industrial applications of paraffin waxes comprised from candles (accounting for around $40-50 \%$ of global market revenue), coatings for wood, paper, packaging, and food products, cosmetics, chewing-gums, crayons, home-care products, pharmaceuticals, polishes, hot-melt adhesives, surf and ski waxes, electrical insulators and tires, plastic and rubber additives (plasticizers), household chemicals, match, inks and rubber industries, binders, flame retardants, powder injection molding, hydrogen production, energy storage, and rheology modifiers [21-23]. The recent studies reported the presence of paraffin waxes at oceans and seas with no further information of stability, retention time, and biodegradability in the ambient. Initial assessments of biodegradation of paraffin waxes deposits in the tanks proved that it takes a time interval of 16 months to start up in marine ambient. Regarding the wide applications of paraffin waxes in packaging purposes, the health effects of these compounds cannot be a serious problem in dermal exposers. The results of both assays of chronic and sub-chronic feeding studies on laboratory animals (like rats, mice, rabbits, etc) confirmed the safety of these kinds of exposures. But the high concentration of paraffin waxes in feeding studies had shown inflammatory responses and histopathological reactions $[24,25]$.

The present review collected the recent developments in the way of IP production technologies all over the world. So, the introduction chapter summarized a brief description of IP toxicity, applications, global demands and production rates, and similar information about it. The tabulated data picked up from industrial projects assessed by the Iranian evaluator team of both Iranian industries organization and the Iranian Environmental Protection Agency in the EIA plan. Therefore, it was implemented a diagram of project identification steps in the EIA plan (in assessing the projects) in parallel with the concept offered by the current review. According to Figure 1 , the current review discussed the selected and relevant technologies posed in the way of paraffin production technologies and noticed the frameworks devised in Iranian industrial projects for IP production and its application in many other projects in Iran. The presented concept moved from project identification information to post-EIA and sustainability assessment in future developments of projects.

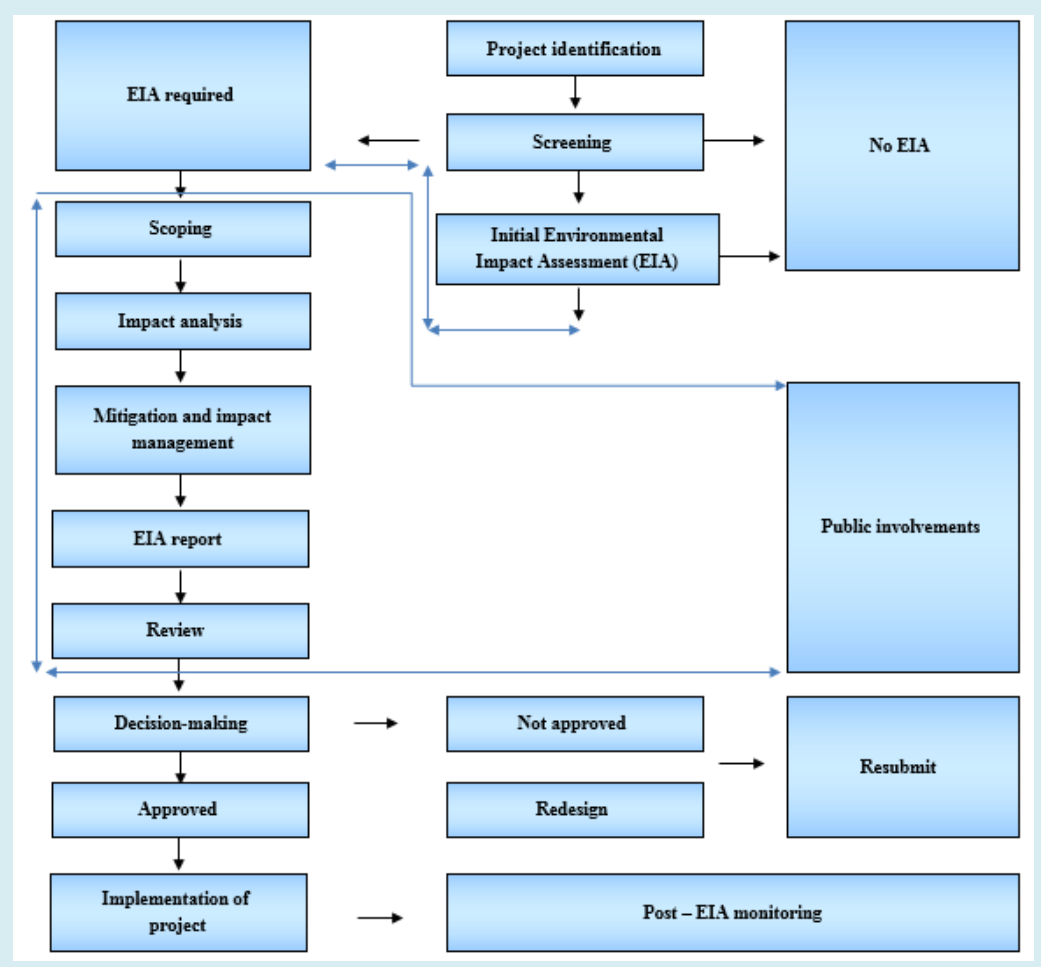

Figure 1: Flow diagram of current review and steps of project identification in EIA plan [26].

\section{Additives Materials and Recent Technologies}

Formulation of paraffin has been recommended by a combination of fatty acids and biosynthesis wax in an elongation operation. Wax is a prominent component of plants that protects them against UV radiation. The produced wax on the plant's surfaces can be modified by additives, biosynthetic gene cloning, crosslinking operation of plasma 


\section{Petroleum \& Petrochemical Engineering Journal}

technology, and similar integrated practices. Also, a mixture of raw and waste materials can be a boost in the manufacturing process as additives materials to wax products as well as employing nanomaterial and nano-composites in this regard [27-31]. Paraffin introduces as a prominent material in the structure of solar stills. The low thermal conductivity of this matter has been modified using nanoparticle additives like Graphene, copper oxide, $\mathrm{Al}$ and Fe oxides, Silicon Nitride, Graphite, and Graphite nanofibres [32-34]. The research of Tang, et al. [35] utilized carbon nanotubes as additives in promoting thermal conductivity and declining cooling properties of paraffin phase change materials [36-39].

\section{Membrane Technology}

A variety of membranes are used in paraffin (methane, ethane, propane, among others)/olefins (ethene, propene, among others) separation based on gaseous and liquid mixtures such as membranes made of Carbon molecular sieves, polymer membranes, Zeolites, Metal-organic frameworks, and mixed matrix membranes. Membranes can be utilized for cryogenic separation operations. It demands a relatively high operation budget. There is a list of advantages and disadvantages for applying membranes in paraffin/olefins segregation technique (1) decline in production outlays (2) decline in equipment and facilities size (3) minimizing energy demand and waste production. The difficulties in handling impurities, breakdown of the segregated materials, low flows in operation, short lifetime, poisoning the membrane surface by some pollutants, and cut off and blockage of membrane surface are the main drawbacks in the utilization of membrane technology [4042]. The decomposition of slack wax by thermal reactors of plasma procures a valuable feedstock of gaseous products for cryogenic and gas capturing operations. The released gaseous products can be reformatted and converted to paraffin and lots of other value-added products for industrial demands [43].

\section{Plasma Reformation}

The reformation of $\mathrm{H}_{2}, \mathrm{CH}_{4}$, and $\mathrm{CO}_{2}$ produces a feedstock of syngas for further processing via Fischer Tropsch synthesis (gasification operation) to produce paraffin wax. Then, using microwave catalytic cracking the paraffin wax produces an enriched gas of $\mathrm{H}_{2}$ for fuel generation purposes. This process can be accomplished by a variety of plasma forces and reactors. The feedstock gas also can be selected from other types of gaseous products of hydrocarbons chains. Using various types of catalytic materials can enhance the reformation operation. However, the efficiency of plasma gasifies and reformers are comparable with catalytic plasma reactors $[44,45]$.

\section{Slack Wax Production Technologies}

To produce IP from crude we need the initial feedstock of slack wax. At first crude oil passes through the fractionation step that this step produces gaseous products, oil, naphtha, gasoline, and kerosene. Then, part of crude oil goes to vacuum fractionation step and the result of this process is lube oil and asphalt. These products are sent to lube tower and solvent de-asphalt towers to further clarification of products. Using solvent is a supplementary step in the removal and segregation of both asphalt and wax. The final product of the solvent de-waxing tower is slack wax which is an initial feed for producing the IP. Slack wax comprised 35-50\% oil in the content. The commercial slack wax holds concentrations of paraffin and sulfur around $79-89 \%$, and $0.5-0.7 \%$ weight percentages respectively [46-48]. The melting point and flash point of slack wax were reported to be around $48-55^{\circ} \mathrm{C}$ and $150^{\circ} \mathrm{C}$ respectively [49,50]. The mentioned steps have been implemented in Figure 2.

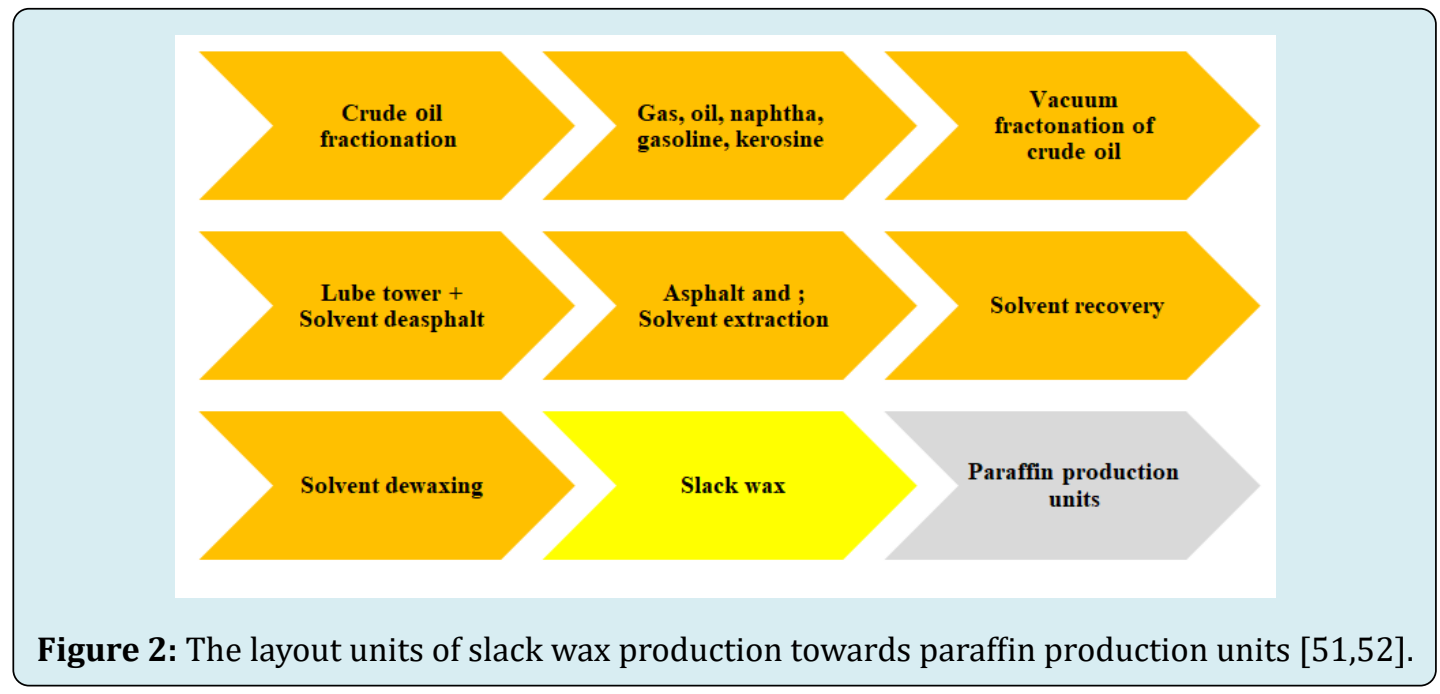




\section{Petroleum \& Petrochemical Engineering Journal}

They are certain types of thermoplastic products with low molecular weight in comparison. But they do not fall into both groups of plastics and polymers. The type of crude oil applied in fractionation operation produces various types of slack waxes in soft and hard enough structures. Also, the quality and quantity of produced slack wax and IP depend on the source of crude oil and slack wax and the rate of assigned fractionation and treatment respectively [18,51]. According to Soliman [51] the purification and treatment technologies of petroleum waxes comprised (1) slack wax and petrolatum production by De-waxing products (2) Refining of the wax products (3) De-oiling and fractional crystallization (4) Percolation process (4) Hydro-finishing process (5) Acid treatment (6) Adsorption process. A study has fulfilled the de-oiling operation of slack wax using static crystallization with the fast proceeding and low outlays [53]. The aforementioned technologies assign to the purification of undesired pollutants and impurities depend on the quality of applied and requested products. Therefore, various configuration of processes, technologies, and facilities is requested in treatment operation [54-57].

\section{IP Production in Iranian Industries}

The IP production processes may be in one of the following ways: (1) Acid/solvent or individual treatment process: In this method, slack wax after re-melting is exposed to cold injection of acid/solvent and mixing by centrifugation to separate impure paraffin. After this operation, the product is dried and purified with sulfuric acid. To remove impurities from the product, the final treatment is fulfilled via filtration. They are molded and finally packed. (2) Sweating process: In this method, slack wax is purified with sulfuric acid after initial molding and lubricant removal. Due to the high production efficiency in the acidic method, this design has been mentioned as the selected method. Numerous samples of slack No. 39 of Tehran Refinery and petroleum and Oil Production and Refining companies of Pars are tested in this regard. To do this, at first $1 \mathrm{~kg}$ of the sample must be picked up and heated to $80^{\circ} \mathrm{C}$ until it becomes completely liquid. Then, employing a spraying system, it is directed into five liters of dichloroethane solvent, which is cooled to $-5^{\circ} \mathrm{C}$. To segregate both solvent and oil phases is utilized the centrifuge unit. Then, the solid residue of the filter is collected and is desiccated into the beaker to be heated. In the next step, after melting, the product is exposed to concentrated sulfuric acid (98-96\%) and is mixed thoroughly by stirring until the acidic sludge phase remains completely at the bottom of the container. The top layer is filtered by passing through the soil (clay) filter. Thus, a pure sample is obtained. One of the disadvantages of using chlorine compounds is that it evaporates in the workplace, which requires the necessary safety and installation of ventilation systems, which must be taken full care of. Another point that should be noted is that the color of the product will change. In other words, oxidizing agents are easily subjected to oxidation, and the presence of such a solvent probably plays a catalytic role against oxygenating agents. As a result, the above solvent can be mixed with a mixture of solvents like a certain percentage of methyl ethyl ketone. With this mixture, not only the color of the product remains white, but all the color compounds are separated from the current and cyclic hydrocarbons. Figure 3 and Table 1 present the layout units and annual requirements of paraffin production industries respectively [58-60].

\begin{tabular}{|c|c|}
\hline The Materials and Equipment & $\begin{array}{c}\text { Total Annual } \\
\text { Rates }\end{array}$ \\
\hline \multicolumn{2}{|c|}{ Equipment and Devices } \\
\hline Centrifuge $800 \mathrm{P} / \mathrm{N}$ & 5 No \\
\hline Mixer $60 \mathrm{~m}^{3}$ & 2 No \\
\hline The tank of crude oil $60 \mathrm{~m}^{3}$ & 3 No \\
\hline Solvent tank $10 \mathrm{~m}^{3}$ & 2 No \\
\hline The tank of extracted oil $60 \mathrm{~m}^{3}$ & $2 \mathrm{No}$ \\
\hline Sweating unit & $1 \mathrm{No}$ \\
\hline Cooling unit & $1 \mathrm{No}$ \\
\hline \multicolumn{2}{|c|}{ Required Materials } \\
\hline Slack wax & $3000 t$ \\
\hline H2SO4/Solvent & $30 t$ \\
\hline \multicolumn{2}{|l|}{ Products } \\
\hline $\begin{array}{l}\text { IP consists of high saturated } \\
\text { hydrocarbons }\end{array}$ & $3000 t$ \\
\hline \multicolumn{2}{|l|}{ Employees } \\
\hline Staff & 29 persons \\
\hline \multicolumn{2}{|c|}{ Energy Consumption } \\
\hline Required water & $11 \mathrm{~m}^{3} /$ day \\
\hline Power & $56 \mathrm{~kW} /$ day \\
\hline Required fuel (Stoves) & $\begin{array}{c}11 \text { Giga Joule/ } \\
\text { day }\end{array}$ \\
\hline \multicolumn{2}{|c|}{ Required Land and Landscaping } \\
\hline Required land & $7200 \mathrm{~m}^{2}$ \\
\hline $\begin{array}{l}\text { Construction of infrastructure } \\
\text { (Buildings) }\end{array}$ & $2055 \mathrm{~m}^{2}$ \\
\hline
\end{tabular}

Table 1: The annual requirements of industries of paraffin [58-60]. 


\section{Petroleum \& Petrochemical Engineering Journal}

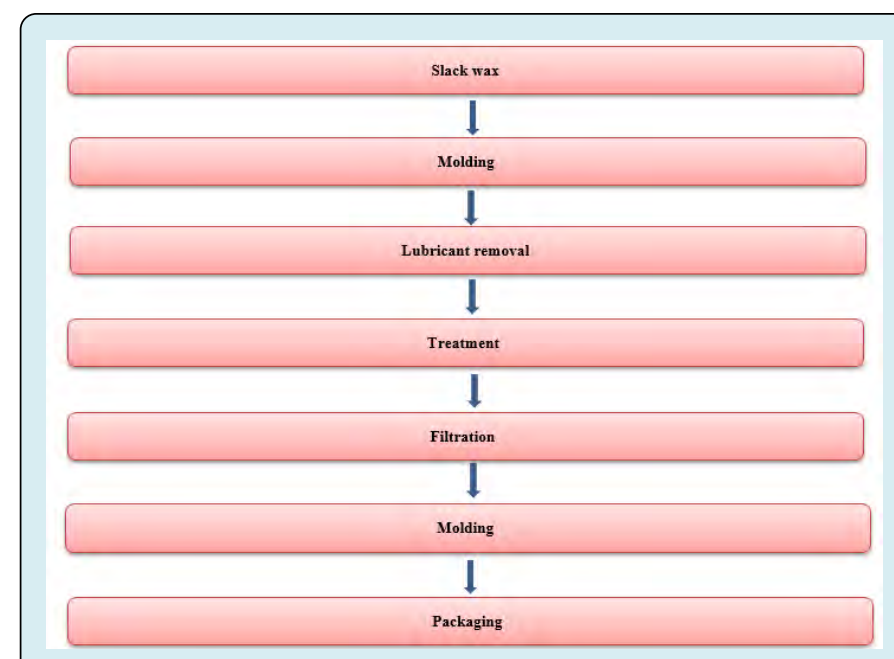

Figure 3: The layout units of paraffin production industries [58-60].

\section{IP as Feedstock of other Industries}

\section{Household Candle}

Paraffin is usually marketed in molds of $5 \mathrm{~kg}$. They are melted in containers heated by electricity. The molten paraffin is then pumped into a paraffin feed tank by a special pump and from there it flows into the molds of the molding machine. At this stage, the candle wick is already placed inside the mold. As soon as the molds are filled, water flows from the water cooler to the molding machine to harden the paraffin inside the molds. Hardening of paraffin takes about 20 minutes, after which the finished candles are taken out of the mold and are usually packed by hand in cellophane bags or cardboard boxes. It should be noted that paraffin is used as a raw material. The allowable concentration of oil in the by-product of oil refining to produce high-quality candles should not exceed $5 \%$, otherwise, it produces smoke when is used. Figure 4 display the layout units and annual requirements of household candle industries Table 2 .

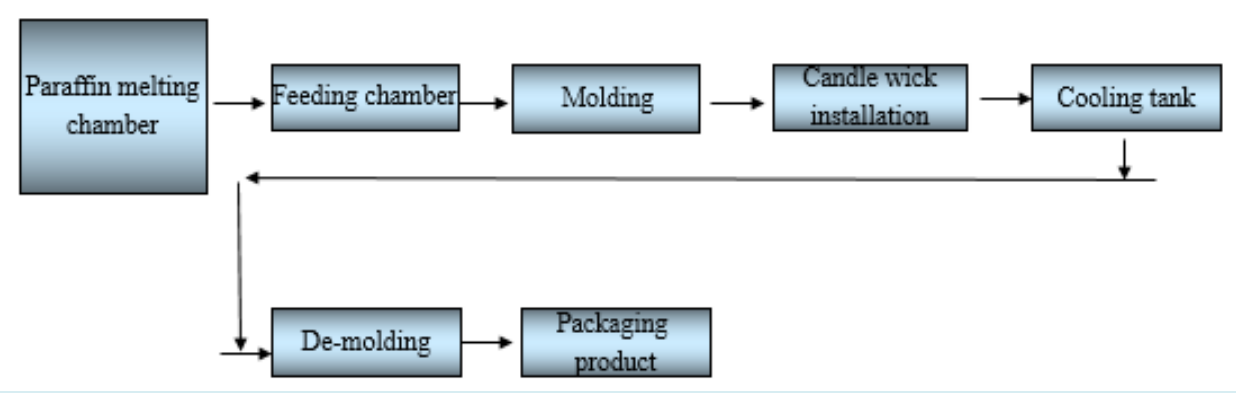

Figure 4: The layout units of household candle [58-60].

\begin{tabular}{|c|c|}
\hline The Materials and Equipment & Total Annual Rates \\
\hline Equipment and Devices & 2 No \\
\hline Paraffin melting chamber & 1 No \\
\hline Paraffin transfer pump & No \\
\hline Feed tanks & 2 No \\
\hline Cooling machine & 1 No \\
\hline Fitted lab & 1 No \\
\hline Required Materials & $335 t$ \\
\hline Paraffin, melting point $=56-640 C$ & 7560000 No \\
\hline Plastic bags, $25 * 5$ cm ${ }^{2}$ & 1260000 No \\
\hline Cardboard for packaging & 1800000 meter \\
\hline Candlewick & \\
\hline Candle, $h=200$ mm, $d=200$ mm, weight $=40 \mathrm{~g}$ & 7560000 No \\
\hline \multicolumn{2}{|l}{} \\
\hline
\end{tabular}




\section{Petroleum \& Petrochemical Engineering Journal}

\begin{tabular}{|c|c|}
\hline \multicolumn{2}{|c|}{ Employees } \\
\hline Staff $\quad$ Energy Consumption & 10 persons \\
\hline Required water & $3 \mathrm{~m} 3 /$ day \\
\hline Power & $46 \mathrm{~kW} / \mathrm{day}$ \\
\hline Required fuel (Stoves) & 2 Giga Joule/day \\
\hline Required Land and Landscaping \\
\hline Required land & $1400 \mathrm{~m}^{2}$ \\
\hline Construction of infrastructure (Buildings) & $405 \mathrm{~m}^{2}$ \\
\hline
\end{tabular}

Table 2: The annual requirements of industries of household candle [58-60].

\section{PVC Pipes}

In the production of PVC fittings, the steps are very different from the pipe production. Due to the fixed form of the parts, the existence of fixed molds, appropriate and standard dimensions, they are closed on the clamp of the machine, and the production process is run at high speed. The main difference observed in the manufacturing processes of pipes and fittings refers to this point that, each part of the mentioned process is done continuously by the machine. While the production line is working, all the components of the line work simultaneously. In the process of producing fittings to make each piece, the process is continuous. The different stages of production are as follows: (1) Weighing and mixing: First, a mixture with certain percentages of materials is prepared: A mixer is used to make a uniform and homogeneous composition. After that, materials are transported to the granulating machine. (2) Granulation: This device is similar to the tube extruder. It consists of a cylinder and a coil with asymmetric coils, which produces the necessary heat on the cylinder to perform the granulation operation on several thermal elements. Granulation is actually a pre-baking step and is done to achieve better product quality. The material passes through a mesh plate at the end of the machine cylinder and is taken out in the form of granules or small lumps by a producing blade. It is transformed from a dough form into a solid grain form by a stream of air as it cools. (3) Extruder: Today, twin-screw extruders with misaligned screws are used to produce pipes. Molten PVC is injected into the extruder and fills a relatively large volume of the head and flows around the mandrel, which is fixed by a spider holder. By changing the core of the mold, the pipes can be produced with different thicknesses and diameters. (4) Pipe stabilization system: The molten pipe must be cooled and its shape is maintained after leaving the extruder unit. 5) Cooling bath: The pipes should be cooled in the stabilization tank and the bath so that their shapes are maintained and they can withstand the stresses of the stretching, twisting, and cutting stages.
6) Pipe pulling unit: This unit is responsible for pulling the pipe at a constant speed with different diameters, different raw materials, and traction units are used with different designs, and usually, those are selected which create the maximum friction capacity between the pipe, the tension belt, and the contact length. 7) Cutting unit: Various systems are available for cutting pipes. Simple vane cutters are often used for small diameter pipes made of soft materials. Radial saws are usually used for pipes with a diameter of up to 200 mm. 8) Connection unit: The selected device in this design can be used for pipes with a diameter of 10 to $710 \mathrm{~mm}$ and the pipes can be the same shape connects. 9) Connection injection device: The injection device has a cylinder and a helix. By reversing the reel by the helix that rotates inside the cylinder. It returns the materials to the cylinder as needed for a period of operation of the device. The doughy molten forms at a temperature of about $65-73^{\circ} \mathrm{C}$. 10) The first steps of clamps and molds: In this stage, the mold, which forms one of the types of joints such as elbows, tees, or transformers are installed on another machine. After loading and heating, the material inside the cylinder and helix is prepared for injection. 11) Injection: After closing the mold with a hydraulic clamp and ensuring complete closure of the mold, the injection operation is performed. At this stage, the molten materials enter into the mold bypassing. The nozzle of the device is located in the cylinder head and the space of the said mold will fill. 12) Drying: After the injection, the material that fills the space inside the mold should be able to completely take the shape of the mold and stabilize to cool. 13) The second stage of the clamp and mold operation: In this stage, after cooling the mold is opened by the clamp and the muscle system operates simultaneously and the muscles come out of the part. Then, by the blade system, the piece is taken out of the mold by the force that enters the piece from the blade. 14) Packaging: After the piece is taken out of the mold, the appendages of the piece are separated by a winner and are placed in plastic bags in certain numbers for packing. Figure 5 and Table 3 represent the layout units and annual requirements of $\mathrm{PVC}$ pipes and fittings producing industries. 


\section{Petroleum \& Petrochemical Engineering Journal}

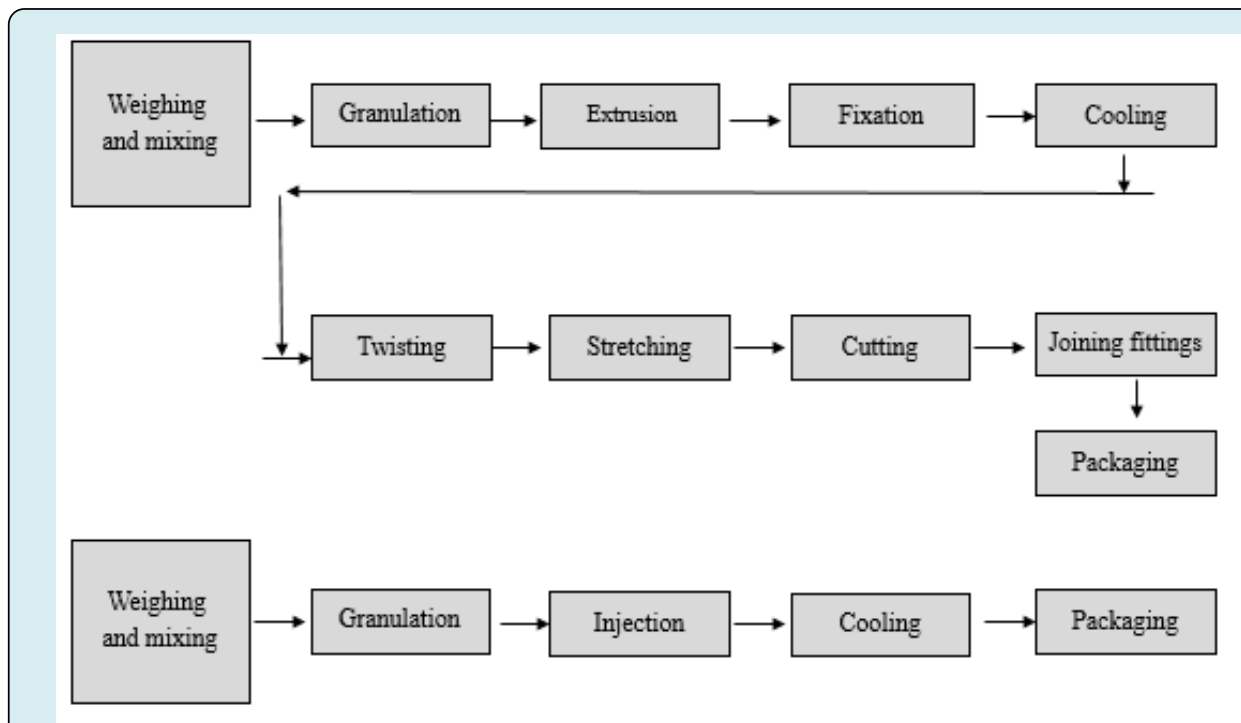

Figure 5: The layout units of PVC pipes and fittings producing industries [58-60].

\begin{tabular}{|c|c|}
\hline The Materials and Equipment & Total Annual Rates \\
\hline \multicolumn{2}{|l|}{ Equipment and devices } \\
\hline Weighbridge, $2000 \mathrm{~kg}$ & $1 \mathrm{No}$ \\
\hline Miller, $1000 \mathrm{~kg} / \mathrm{h}, 22 \mathrm{~kW}$ & $1 \mathrm{No}$ \\
\hline Mixer, $300 \mathrm{~kg} / \mathrm{h}, 32.5 \mathrm{~kW}, 14-28 \mathrm{~m} / \mathrm{s}$ & 1 No \\
\hline Granule maker machine, $300 \mathrm{~kg} / \mathrm{h}, 73 \mathrm{~kW}$ & $1 \mathrm{No}$ \\
\hline Pipe production line, $200-250 \mathrm{~kg} / \mathrm{h}, \mathrm{d}=40-250 \mathrm{~mm}$ & 1 No \\
\hline Injection machine, $\mathrm{d}=48 \mathrm{~mm}, 1147 \mathrm{bar}$, maximum injected weight $242 \mathrm{~g}$ & $1 \mathrm{No}$ \\
\hline Injection machine, $\mathrm{d}=50 \mathrm{~mm}, 1510 \mathrm{bar}$, maximum injected weight, $374 \mathrm{~g}$ & $1 \mathrm{No}$ \\
\hline Molds & 10 No \\
\hline Fitted lab and repair workshop & 1 and 1 No \\
\hline \multicolumn{2}{|l|}{ Required materials } \\
\hline PVC powder & $1287 \mathrm{t}$ \\
\hline $\mathrm{CaCO}_{3}$ as filler & $72 \mathrm{t}$ \\
\hline Stabilizer & $34 \mathrm{t}$ \\
\hline Paraffin lubricant & $7 \mathrm{t}$ \\
\hline PE bag & $4 \mathrm{t}$ \\
\hline \multicolumn{2}{|l|}{ Products } \\
\hline PVC Pipes, $\mathrm{d}=2-31.5 \mathrm{~cm}$ & $1200 \mathrm{t}$ \\
\hline PVC fittings, $d=2-31.5 \mathrm{~cm}$ & $200 t$ \\
\hline \multicolumn{2}{|l|}{ Employees } \\
\hline Staff & 29 persons \\
\hline \multicolumn{2}{|l|}{ Energy consumption } \\
\hline Required water & $7 \mathrm{~m}^{3} /$ day \\
\hline Power & $289 \mathrm{~kW} /$ day \\
\hline Required fuel (Stoves) & 5 Giga Joule/day \\
\hline \multicolumn{2}{|l|}{ Required land and landscaping } \\
\hline Required land & $3200 \mathrm{~m}^{2}$ \\
\hline Construction of infrastructure (Buildings) & $925 \mathrm{~m}^{2}$ \\
\hline
\end{tabular}

Table 3: The annual requirements of industries of PVC pipes and their fittings [58-60]. 


\section{Petroleum \& Petrochemical Engineering Journal}

\section{Shoe Wax}

The process of producing wax is performed via mixing and heating the raw materials with gradual cooling and packing. All these operations are accomplished under atmospheric pressure and temperature of 100 . All equipment and facilities are made of stainless steel. The completion of the mixing process is related to the speed of the mixers, and the production rate of the filling machine. After weighing, the materials are directed to a double-walled tank that includes a mixer and boiling water or water vapor within the chamber. Since the melting point of most waxes is 50 , the material inside the tank reaches the melting temperature, and the stirring causes them to mix better. The materials that are first poured into the tank are petroleum and mineral solvents. Then, paraffin wax, carnauba wax, and dye are added. After ensuring the right running of the operation, the product is transferred to the can filling machines by a stainless steel gear pump. The process of filling the cans or tubs is automatic. After filling, the wax cans enter the cooling tunnel. Because the materials are almost liquid up to a temperature above 90, their gradual cooling takes longer, which in turn slows down transportation and storage operation. At the time of production of liquid wax, a temperature of $50^{\circ} \mathrm{C}$ is sufficient and the boiler doesn't need to raise the temperature of the tank to $100^{\circ} \mathrm{C}$. Figure 6 and Table 4 denote the layout units and annual requirements of shoe wax industries respectively.

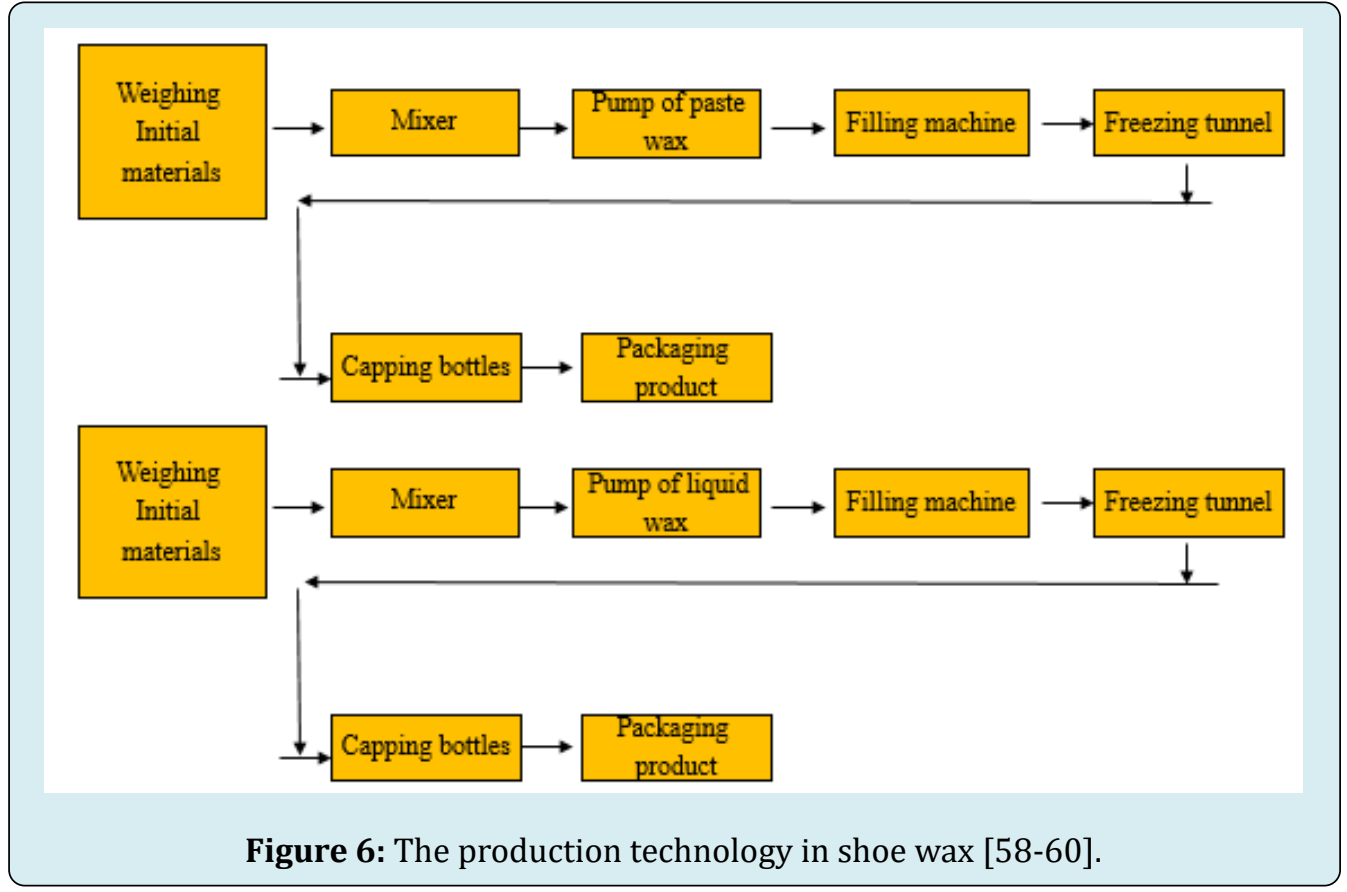

\begin{tabular}{|c|c|}
\hline The Materials and Equipment & Total Annual Rates \\
\hline \multicolumn{2}{|c|}{ Equipment and Devices } \\
\hline Wax production line along with double layers mixer & 1 No \\
\hline Tank equipped to the mixer, stainless steel & 1 No \\
\hline Pump for filling bottles containing 2 nozzles and semi-automatic \\
\hline Conveyor of the cooling tunnel, L= 3 m & 2 No \\
\hline Liquid wax along with filling materials & 11 No \\
\hline Automatic mixing tank & 1 No \\
\hline Required Materials & $42600 \mathrm{~L}$ \\
\hline Turpentine & $107000 \mathrm{~kg}$ \\
\hline Solid paraffin & $33330 \mathrm{~kg}$ \\
\hline Artificial wax & $3640 \mathrm{~kg}$ \\
\hline Colophon &
\end{tabular}




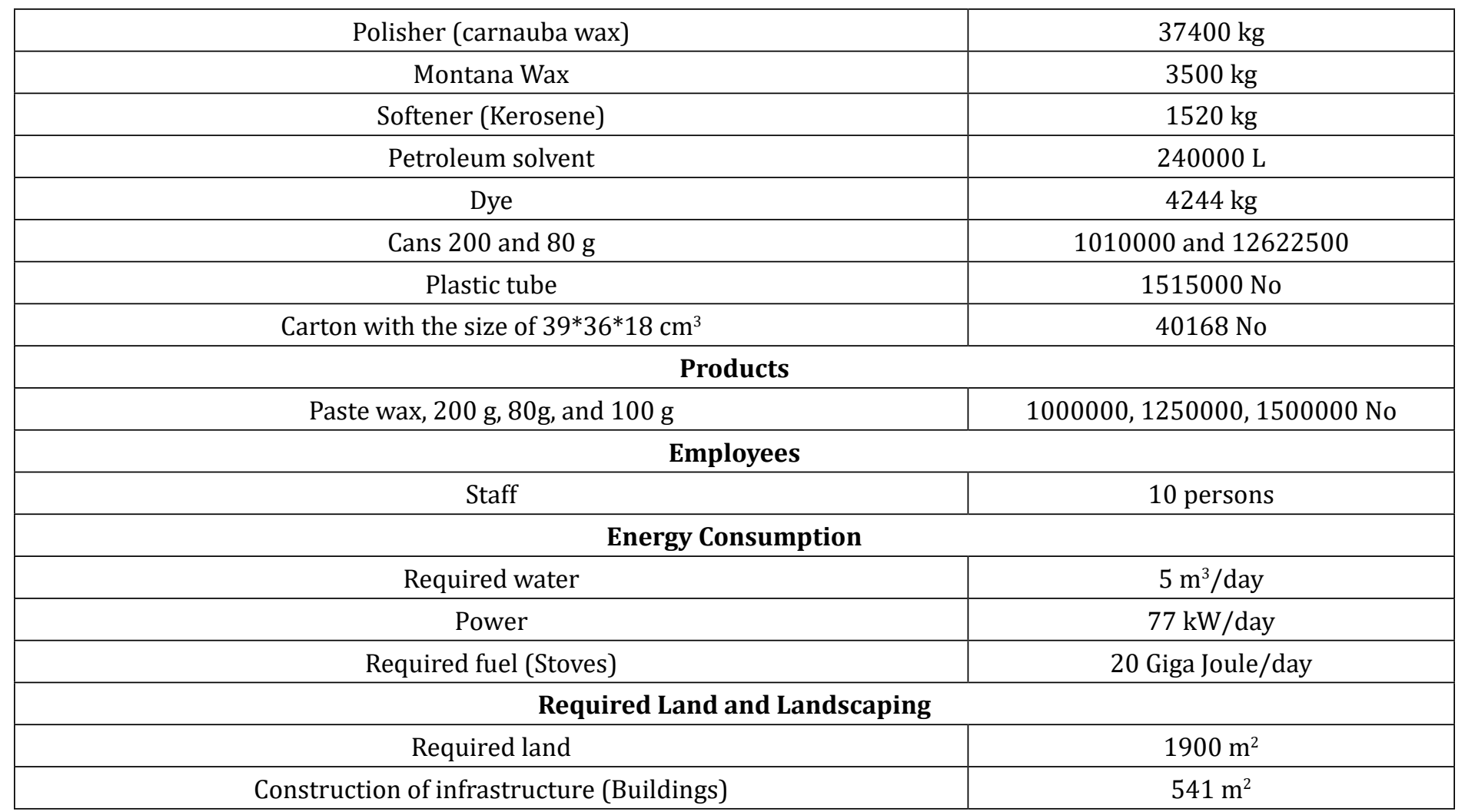

Table 4: The annual requirements of industries of shoe wax [58-60].

\section{Matchstick Producing Industries}

In the matchstick producing unit, the timbers are configured in determining shapes, molds, and sizes. The designed pieces are left to be dried to the lowest moisture percentage of $7 \%$. Then, they are sorted out based on the quality of the body to be ready for taking up paraffin, chemicals, and additives. There are some other units for the final preparation of matchstick pieces such as making boxes, labeling, storage of products, etc. Figure 7 shows the layout of units of matchstick manufacturing industries. Table 5 comprised the annual requirements of industries of a matchstick.

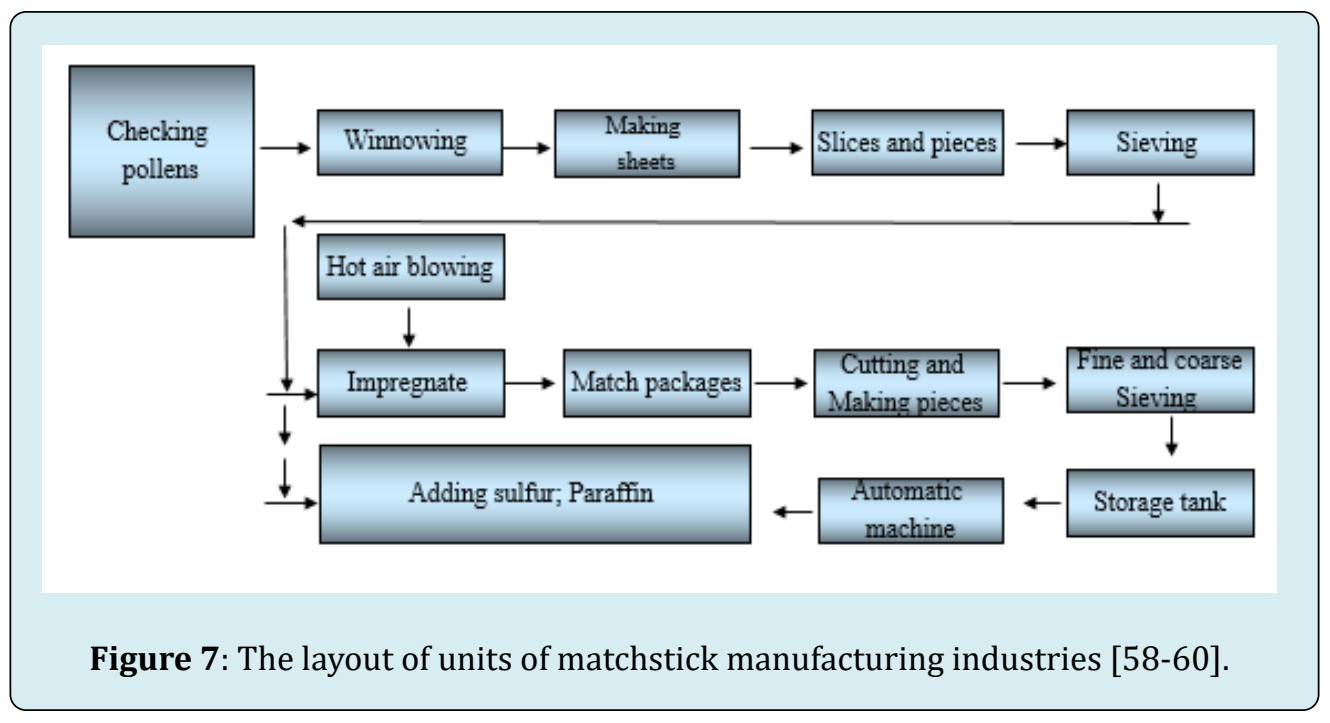




\section{Petroleum \& Petrochemical Engineering Journal}

\begin{tabular}{|c|c|}
\hline The Materials and Equipment & Total Annual Rates \\
\hline \multicolumn{2}{|l|}{ Equipment and Devices } \\
\hline Circular saw, $2 \mathrm{~kW}$ & $1 \mathrm{No}$ \\
\hline Peeling machine, Capacity of 18 million & $1 \mathrm{No}$ \\
\hline A wood grinding machine, $2.5 \mathrm{~kW}, 18$ million wood $/ \mathrm{h}$ & $1 \mathrm{No}$ \\
\hline Saturation and dyeing machine, $0.2 \mathrm{~kW}, 18$ million woods & 1 No \\
\hline Drying chamber, 8 kW, capacity 18 million wood/h (1 No) & 1 No \\
\hline Casting and polishing machine, $0.6 \mathrm{~kW}, 18$ million woods $/ \mathrm{h}$ & $1 \mathrm{No}$ \\
\hline Small chip separate, $0.2 \mathrm{~kW}, 18$ million wood $/ \mathrm{h}$ & $1 \mathrm{No}$ \\
\hline Disassembly chips, $0.3 \mathrm{~kW}, 18$ million wood $/ \mathrm{h}$ & $1 \mathrm{No}$ \\
\hline Buffing machine, $0.75 \mathrm{~kW}, 18$ million woods $/ \mathrm{h}$ & $1 \mathrm{No}$ \\
\hline Chip collection device, $1.5 \mathrm{~kW}, 18$ million woods $/ \mathrm{h}$ & $1 \mathrm{No}$ \\
\hline Match producing machine, $20 \mathrm{~kW}, 20000$ matches box $/ \mathrm{h}$ & 1 No \\
\hline Furnace, $20 \mathrm{~kW}$ & $1 \mathrm{No}$ \\
\hline Air dryer, $10 \mathrm{~kW}$ & $1 \mathrm{No}$ \\
\hline Disintegrating mixing device, $0.5 \mathrm{~kW}, 18$ million woods $/ \mathrm{h}$ & $1 \mathrm{No}$ \\
\hline Gelatin melting machine, $200 \mathrm{~L}$ & $1 \mathrm{No}$ \\
\hline Cutting machine, $2 \mathrm{~kW}, 18$ million wood/h & $1 \mathrm{No}$ \\
\hline Cutting machine, $2 \mathrm{~kW}, 18$ million wood $/ \mathrm{h}$ & 1 No \\
\hline Box machine, $1 \mathrm{~kW}, 20000$ boxes $/ \mathrm{h}$ & $1 \mathrm{No}$ \\
\hline Matching sticker machine, $2 \mathrm{~kW}, 18$ million wood/h & 1 No \\
\hline Box filling machine, $2 \mathrm{~kW}, 18$ million wood $/ \mathrm{h}$ & 1 No \\
\hline Milling chemical materials, $2 \mathrm{~kW}, 18$ million wood $/ \mathrm{h}$ & $1 \mathrm{No}$ \\
\hline Chemical material coverage, $1.5 \mathrm{~kW}, 18$ million wood $/ \mathrm{h}$ & $1 \mathrm{No}$ \\
\hline Brush making machine, $1.5 \mathrm{~kW}, 18$ million wood $/ \mathrm{h}$ & 1 No \\
\hline Packaging machine, $1.5 \mathrm{~kW}, 18$ million woods $/ \mathrm{h}$ & 1 No \\
\hline \multicolumn{2}{|l|}{ Materials Demands } \\
\hline Timber & $970 \mathrm{~m}^{3}$ \\
\hline Potassium chlorate $92 \%$ & $34 \mathrm{t}$ \\
\hline Red phosphorous & $14 \mathrm{t}$ \\
\hline Paraffin wax & $25.8 \mathrm{t}$ \\
\hline Gum & $9.7 \mathrm{t}$ \\
\hline Sulfur $60 \%$ & $8.1 \mathrm{t}$ \\
\hline Resin powder & $4.9 \mathrm{~kg}$ \\
\hline $\mathrm{MnO}_{2} 85 \%$ & $3.6 \mathrm{t}$ \\
\hline Antimony sulfide $60 \%$ & $3.6 \mathrm{t}$ \\
\hline Chemical additives & $0.5 \mathrm{t}$ \\
\hline Paper cans, $310 \mathrm{~g} / \mathrm{m}^{2}$ & 2.2 million rolls \\
\hline Paper cans, $240 \mathrm{~g} / \mathrm{m}^{2}$ & 86.4 million rolls \\
\hline Packaging paper & 880 rolls \\
\hline Products & \\
\hline
\end{tabular}




\section{Petroleum \& Petrochemical Engineering Journal}

\begin{tabular}{|c|c|}
\hline Matchsticks & \multicolumn{2}{|c|}{7776 packages } \\
\hline \multicolumn{1}{|c|}{ Employees } & 41 persons \\
\hline Staff & $9 \mathrm{~m}^{3} /$ day \\
\hline Energy Consumption & $330 \mathrm{~kW} /$ day \\
\hline Required water & 48 Giga Joule/day \\
\hline Power & $5100 \mathrm{~m}^{2}$ \\
\hline Required fuel (Stoves) & $1460 \mathrm{~m}^{2}$ \\
\hline Required Land and Landscaping
\end{tabular}

Table 5: The annual requirements of industries of a matchstick [58-60].

\section{Conclusion}

The fractionation technology produces miscellaneous products of petroleum waxes. Also, the miscellaneous products are able to come out via fractions of slack wax. A variety of products can be defined based on the layout of units of technologies regarding the outputs produced of fractionations of crude oil. The quality and quantity of products are in close dependence on the layout of units of different technologies and properties of initial feedstock. Slack wax as a by-product of crude fractionation was taken into consideration to produce value-added materials. The data listed in tables facilitate the way to the financial assessment of industrial projects by simple financial equations or by using data envelopment analysis. Therefore, future studies will assent to figure out which technology has economic viability? And by the way, it will find the way for completing the EIA plan. The existing concepts possess to allocate too many criteria and alternatives for the decisionmakers in decision science theory. The sustainability of future IP production technologies depends on findings of decision science in introducing the best alternative. The best alternative will mitigate the dangerous health effects of implemented technology and its impacts on the environment and human well-being. It also brings the sustainability of the project for a long time.

\section{Acknowledgment}

This research was conducted as part of the corresponding author's Ph.D. research work (Entitled; Evaluation of 405 Iranian Industries). The tabulated data were picked up from the screening step of project identification in environmental impact assessment. The author thanked colleagues and evaluators of both the Iranian environment protection agency and Iranian industries organization for the data assessed.

\section{Competing Interests}

The author declares that there is no competing interests.

\section{Conflict of Interest}

There is no conflict of interest.

\section{Funding}

None.

\section{Ethical Considerations} author.

Ethical issues have been completely observed by the

\section{References}

1. Bachmann RT, Johnson AC, Edyvean RGT (2013) Biotechnology in the petroleum industry: An overview. International Biodeterioration \& Biodegradation 86C: 225-237.

2. Jimenez-Diaz L, Caballero A, Perez-Hernandez N, Segura A (2017) Microbial alkane production for jet fuel industry: motivation, state of the art and perspectives. Microbial Biotechnology 10(1): 103-124.

3. Sharip MS, Sazali N, Jamaludin AS, Azmi MAM, Aziz F, et al. (2019) Current advancement by membrane technology: A Review. Journal of Advanced Research in Fluid Mechanics and Thermal Sciences 59(2): 283-290.

4. Rana MS, Samano V, Ancheyta J, JAI Diaz (2007) A review of recent advances on process technologies for upgrading of heavy oils and residua. Fuel 86(9): 1216-1231. 


\section{Petroleum \& Petrochemical Engineering Journal}

5. Youssef N, Elshahed MS, McInerney MJ (2009) Microbial processes in oil fields: culprits, problems and opportunities. Adv Appl Microbiol 66: 141-251.

6. Jinfeng L, Lijun M, Bozhong M, Rulin L, Fangtian N, et al. (2005) The field pilot of microbial enhanced oil recovery in a high temperature petroleum reservoir. J Petrol Sci Eng 48(3-4): 265-271.

7. Lazar I, Voicu A, Nicolescu C, Mucenica D, Dobrota S, et al. (1999) The use of naturally occurring selectively isolated bacteria for inhibiting paraffin deposition. J Petrol Sci Eng 22(1-3): 161-169.

8. Hao RX, Lu AH, Zeng Y (2004) Effect on crude oil by thermophilic bacterium. J Petrol Sci Eng 43(3-4): 247258.

9. Nelson L, Schneider DR (1993) Six years of paraffin control and enhanced oil recovery with the microbial product, Para-BacTM. Develop Petrol Sci 39: 355-362.

10. Bailey SA, Kenney TM, Schneider DR (2001) Microbial enhanced oil recovery: diverse successful applications of biotechnology in the oil field. The SPE Asia Pacific Improved Oil Recovery Conference Held in Kuala Lumpur, Society of Petroleum Engineers, Malaysia.

11. Sivakumar P, Sircar A, Deka B, Anumegalai AS, Moorthi PS, et al. (2018) Flow improvers for assured flow of crude oil in midstream pipeline-A review. J Pet Sci Eng 164: 24-30.

12. Theyab MA (2020) A Review of Wax Mitigation Methods through Hydrocarbon Production. J Pet Environ Biotechnol 11(5): 1-11.

13. Theyab M (2017) Study of Fluid Flow Assurance in Hydrocarbon Production-Investigation Wax Mechanisms. PhD Thesis, pp: 1-200.

14. White M, Pierce K, Acharya T (2018) A Review of WaxFormation/Mitigation Technologies in the Petroleum Industry. SPE Prod \& Oper 33(3): 476-485.

15. Ajayi OE (2013) Modelling of Controlled Wax Deposition and Loosening in Oil and Gas Production Systems. Master's Thesis, Institutt for Energi-Og Prosessteknikk, Trondheim, Norway.

16. Rehan M, Nizami AS, Taylan 0, Al-Sasi BO, Demirbas A (2016) Determination of wax content in crude oil. Pet Sci Technol 34: 799-804.

17. Ganeeva YM, Yusupova TN, Romanov GV (2016) Waxes in asphaltenes of crude oils and wax deposits. Pet Sci 13: 737-745.
18. El-Dalatony MM, Jeon BH, Salama ES, Eraky M, Kim WB, et al. (2019) Occurrence and Characterization of Paraffin Wax Formed in Developing Wells and Pipelines. Energies 12(6): 967.

19. Farragher SM, Tanney A, Kennedy RD, Harkin DP (2008) RNA expression analysis from formalin Fixed Paraffin embedded tissues. Histochem Cell Biol 130(3): 435-445.

20. Mohammad M, Hari TK, Yaakob Z, Sharma YC, Sopian K (2013) Overview on the production of paraffin basedbiofuels via catalytic hydrodeoxygenation. Renewable and Sustainable Energy Reviews 22:121-132.

21. Suaria G, Aliani S, Merlino S, Abbate M (2018) The Occurrence of Paraffin and Other Petroleum Waxes in the Marine Environment: A Review of the Current Legislative Framework and Shipping Operational Practices. Frontiers in Marine Science 5: 94.

22. Samieadel A, Fini EH (2020) Interplay between Wax and Polyphosphoric Acid and Its Effect on Bitumen Thermo mechanical Properties. Construction and building materials 243.

23. Mohamed NH, Soliman FS, Maghraby HEI, Moustfa MY (2017) Thermal conductivity enhancement of treated petroleum waxes, as phase change material, by $\alpha$ nano alumina: Energy storage. Renewable and Sustainable Energy Reviews 70: 1052-1058.

24. Grand View Research (2017) Paraffin Wax Market Analysis by Application (Candles, Packaging, Cosmetics, Hotmelts, Board Sizing, Rubber), By Region (North America, Europe, Asia Pacific, Central \& South America, Middle East \& Africa), By Country, And Segment Forecasts, 2014 - 2025. Technical Report, pp: 80.

25. Dwivedi AP, Ghosal G, Belkhode P (2017) Studies in properties of microcrystalline and paraffin waxes with the help of Gas Chromatography (GC), DSC, FT-IR and by conventional methods. Int J Sci Res Sci Technol 3: 922929.

26. Lohani BN, JW Evans, RR Everitt, H Ludwig, Richard AC, et al. (1997) Environmental Impact Assessment for Developing Countries in Asia. Volume 1-Overview, Asian Development Bank, pp: 356.

27. Denes FS, Manolache S (2004) Macromolecular plasmachemistry: an emerging field of polymer science. Prog Polym Sci 29(8): 815-885.

28. Post-Beittenmiller D (1996) Biochemistry and molecular biology of wax production in plants. Annu Rev Plant Physiol Plant Mol Biol 47: 405-430. 


\section{Petroleum \& Petrochemical Engineering Journal}

29. Siow KS, Britcher L, Kumar S, Griesser HJ (2006) Plasma Methods for the Generation of Chemically Reactive Surfaces for Biomolecule Immobilization and Cell Colonization - A Review. Plasma Process Polym 3(6-7): 392-418.

30. Gitis NV (2008) Tribology Testing of Lubricating Oils with Nano-Additives. Center for Tribology, Inc, Campbell, USA.

31. Joly-Pottuz L, Dassenoy F, Martin JM, Vrbanic D, Mrzel A, et al. (2005) Tribological properties of Mo S I nanowires as additive in oil. Tribol Lett 18(3): 385-393.

32. Safaei MR, Goshayeshi HR, Chaer I (2019) Solar Still Efficiency Enhancement by Using Graphene Oxide/ Paraffin Nano-PCM. Energies 12(10): 1-13.

33. Sheikholeslami, M (2018) Numerical simulation for solidification in a LHTESS by means of nano-enhanced PCM. J Taiwan Inst Chem Eng 86: 25-41.

34. Shahsavar A, Khanmohammadi S, Karimipour A, Goodarzi M (2019) A novel comprehensive experimental study concerned synthesizes and prepare liquid paraffin- $\mathrm{Fe}_{3} \mathrm{O}_{4}$ mixture to develop models for both thermal conductivity \& viscosity: A new approach of GMDH type of neural network. Int J Heat Mass Transf 131: 432-441.

35. Tang Q Sun J, Yu S, Wang G (2014) Improving thermal conductivity and decreasing supercooling of paraffin phase change materials by $n$-octadecylaminefunctionalized multiwalled carbon nanotubes. RSC Advances 69: 1-9.

36. Abidin SZ, Ghani SAA, Osarieme UO, Jamari SS (2020) Characterization of Stearic Acid and Paraffin Incorporated with Aluminium as Filer for the Development of Phase Change Material Composite in Thermal Energy Storage. IOP Conf Series: Materials Science and Engineering 991: 012077.

37. Xu G, Xue Y, Zhao Z, Lian X, Lin H, et al. (2018) Influence of poly(methacrylate-co-maleic anhydride) pour point depressant with various pendants on low-temperature flowability of diesel fuel. Fuel 216: 898-907.

38. Zaky MT, Mohamed NH, Farag AS (2011) Separation of some paraffin wax grades using solvent extraction technique. Fuel Process Technol 92(10): 2024-2029.

39. Chanda D, Sarmah A, Borthakur A, Rao KV, Subrahmanyam B, et al. (1998) Combined effect of asphaltenes and flow improvers on the rheological behaviour of Indian waxy crude oil. Fuel 77(11): 1163-1167.

40. De Miranda DMV, Dutra LDS, Way D, Amaral N, Wegenast
F, et al. (2019) A Bibliometric Survey of Paraffin/Olefin Separation Using Membranes. Membranes 9(12): 157.

41. Rungta M, Zhang C, Koros WJ, Xu L (2013) Membranebased ethylene/ethane separation: The upper bound and beyond. AIChE J 59(9): 3475-3489.

42. Eldridge RB (1993) Olefin/paraffin separation technology: a review. Ind Eng Chem Res 32(10): 22082212.

43. Hassanpour, M (2020) Techno-economic assessment of recycling acidic sludge project of reprocessing industries to value-added gaseous products using Plasmatron. Environ health eng manag 7(3): 183-192.

44. Gonzalez-Cortes $\mathrm{S}$, Slocombe DR, Xiao T, Aldawsari A, Yao $B$, et al. (2016) Wax: A benign hydrogen-storage material that rapidly releases. $\mathrm{H}_{2}$-rich gases through microwave assisted catalytic decomposition. Scientific reports 6: 35315.

45. Brouwer T, Schuur B (2020) Bio-based solvents as entrainers for extractive distillation in aromatic/ aliphatic and olefin/paraffin separation. Green Chem 22: 5369-5375.

46. Alvarez-Majmutov A, Gieleciak R, Chen J (2015) Deriving the Molecular Composition of Vacuum Distillates by Integrating Statistical Modeling and Detailed Hydrocarbon Characterization. Energy Fuels 29(12): 7931-7940.

47. Hu G, Li J, Zeng G (2013) Recent development in the treatment of oily sludge from petroleum industry: A review. Journal of Hazardous Materials 261: 470-490.

48. Hani FB, Al-Wedyan H (2011) Regeneration of base-oil from waste-oil under different conditions and variables. African Journal of Biotechnology 10(7): 1150-1153.

49. Saleem MO (2013) Treatment of Slack Wax By Thermal and Catalytic Cracking Processes. Ph.D. Thesis, University of Baghdad, Chemical Engineering Department, Iraq.

50. Mohammed AHAK, Obeyed SM (2013) Treatment of Slack Wax by Thermal Cracking Process. Iraqi Journal of Chemical and Petroleum Engineering 15(3): 1-7.

51. Soliman FS (2020) Introductory Chapter: Petroleum Paraffins. Paraffin - an Overview. IntechOpen, pp: 1-9.

52. Guthrie VB (1960) Petroleum Products Handbook. McGraw-Hill, Newyork, USA.

53. Karpenko OV, Grushova EI (2016) Intensification of paraffin wax separation from oil stocks by static 
crystallization. Proceedings of BSTU 4: 40-43.

54. Bai G, Fan Q, Sun J, Cheng L, Song X-M (2019) A novel forced separation method for the preparation of paraffin with excellent phase changes. RSC Adv 9: 30453-30460.

55. Beasley BE (2017) Conventional Lube Base Stock. Handbook of Petroleum Technology, Springer, pp: 9571013.

56. Gao L, Li C, Huang W, Mei S, Lin H, et al. (2020) MXene/ Polymer Membranes: Synthesis, Properties, and Emerging Applications. Chem Mater 32(5): 1703-1747.

57. Mohammed MAM (2019) Enhancement of the Physical and Molecular Properties of Sudanese Crude Oil (Rawat) Using Solvent Dewaxing Process. Sudan University of Science and Technology, College of Graduate Studies, Sudan, pp: 1-135.

58. Iranian industries organization website, Evaluation of industrial projects.

59. Small Industries Organization and industrial States of Iran.

60. Database of Iranian Industries organization (2005) Released in a package; Evaluation of industrial projects. 